\title{
Służba strażników Stalagu VIII B Lamsdorf w czasie II wojny światowej. Regulaminy i realia
}

Streszczenie. Służbę strażników w obozie Lamsdorf oraz innych obozach jenieckich Wehrmachtu normowały regulaminy, szczegółowo określające zakres obowiązków i zasady zachowania. Jednakże sposób, w jaki wywiązywali się ze swych powinności, niejednokrotnie odbiegał od wytycznych zawartych w rozporządzeniach wydawanych przez zwierzchników. Monotonia służby, chęć zdobycia deficytowych towarów czy wręcz dążenie do poprawy sytuacji materialnej skłaniały żołnierzy do łamania praw, którym podlegali. Problemy strażników z prawem i regulaminami są tematem dosyć istotnym, bo przekładały się m.in. na stosunek do jeńców i ich traktowanie.

Słowa kluczowe: niewola, jeniec, stalag, strażnik.

$\mathbf{J}$ eńcy to żołnierze, którzy w czasie wojny angażowali się w działania bojowe pod rozkazami swojego rządu i zostali zatrzymani przez siły zbrojne strony przeciwnej, dostając się w ten sposób do niewoli. Podczas II wojny światowej Niemcy utworzyły całą sieć obozów odosobnienia dla pojmanych żołnierzy państw alianckich. W obozach przejściowych (Durchgangslager, Dulag) dokonywano ich rejestracji oraz klasyfikacji: szeregowi i podoficerowie trafiali do stalagów, tj. stałych obozów jenieckich dla podoficerów i szeregowych (Manschaftsstammlager), zaś oficerowie do oflagów (Offizierslager). Pobyt w nich różnił się zasadniczo z uwagi na przepisy Konwencji dotyczącej traktowania jeńców wojennych, podpisanej w Genewie dnia 27 lipca 1929 r., zgodnie z zapisami której oficerowie byli zwolnieni od pracy, natomiast pozostałych jeńców obejmował przymus pracy (podoficerowie na stanowiskach nadzorczych). Istniały ponadto obozy m.in. dla lotników, marynarzy, repatriantów¹.

*Dział Naukowy, e-mail: e.klimczak@cmjw.pl.

${ }^{1}$ R. K o b y 1 a r z, K. S z n o t a 1 a, Niemiecki system jeniecki 1939-1945. Wykaz obozów, Opole 2010; A. M a t u c h n i a k-K r a s u s k a, Za drutami oflagów. Jeniec wojenny 613/X A, Opole 2016, s. 13; P. S t a n e k, W niewoli niemieckiej. Informator wystawy stałej Centralnego Muzeum Jeńców Wojennych w Lambinowicach-Opolu, Opole 2011, s. 11-13. 
Stalag VIII B² Lamsdorf (obecnie Łambinowice) na Śląsku Opolskim był jednym z największych obozów przymusowego pobytu dla żołnierzy państw walczących z Niemcami podczas II wojny światowej (1939-1945)3. Pierwsi jeńcy tego obozu to żołnierze Wojska Polskiego z kampanii polskiej 1939 r. ${ }^{4}$ Od połowy $1940 \mathrm{r}$. przetrzymywano w nim zasadniczo ${ }^{5}$ żołnierzy armii brytyjskiej ${ }^{6}$, w tym z kolonii. Około 1,5 km dalej istniał Stalag 318/VIII F Lamsdorf dla jeńców Armii Czerwonej $^{7}$, a w późniejszym okresie wojny także powstańców warszawskich ${ }^{8}$, który szybko stracił swą samodzielność, stając się częścią Stalagu VIII B, a następnie Stalagu 344 Lamsdorf. Należy wskazać, że w niewoli niemieckiej przebywało ok. 8 milionów jeńców wielu narodowości, z wielu armii świata. Byli oni traktowani w różny sposób, mówiąc najogólniej, w zależności od tego, jakiej armii byli żołnierzami - wytworzyła się swoista hierarchia9.

${ }^{2}$ Zgodnie z rozkazem obozowym nr 93 z 24 XI 1943 r. Stalag VIII B Lamsdorf został przeniesiony do Teschen (Cieszyn), zaś dotychczasowy stalag Lamsdorf został przemianowany na Stalag 344 Lamsdorf - Rozkaz obozowy nr 93. Podziat Stalagu VIII B, „,Szkice z dziejów obozów w Lamsdorf/Łambinowicach. Historia i współczesność”, z. 3, red. E. Nowak, Opole 2007, s. 128.

3 J. S a w c z u k, S. S e n f t, Obozy jenieckie w Lamsdorf w latach II wojny światowej, [w:] Obozy w Lamsdorf/Lambinowicach (1870-1946), red. E. Nowak, Opole 2006, s. 117-260.

${ }^{4}$ Ibidem, s. 138-139. Vide: P. S t a n e k, Wrześniowy epilog. Żolnierze Wojska Polskiego w obozach Lamsdorf, seria: „Jeńcy Lamsdorf”, t. IV, Opole 2017.

${ }^{5}$ Wśród jeńców byli też Francuzi, Włosi oraz powstańcy słowaccy. W sumie żołnierze z dziesięciu armii i pochodzący z kilkudziesięciu narodów. Szerzej: S. S e n ft, Włoscy jeńcy wojenni w Stalagu 344 Lamsdorf, „Szkice z dziejów obozów w Lamsdorf/Łambinowicach. Historia i współczesność", z. 2, red. E. Nowak, Opole 2000, s. 61-74; E. N o w a k, Powstańcy stowaccy w Stalagu 344 Lamsdorf (1944-1945), ibidem, s. 75-84.

${ }^{6}$ Cf. R. B e d n or z, Żotnierze brytyjscy za drutami Stalagów VIII B i 344 w Lamsdorf-Łambinowicach, „Lambinowicki Rocznik Muzealny” 1993, t. XVI, s. 9-27; A. W i c k i e w i c z, Niewola w brytyjskim mundurze. Stalag VIII B (344) Lamsdorf, „Jeńcy Lamsdorf”, t. II, Opole 2016.

${ }^{7}$ Cf. Dziennik jeńca wojennego Siergieja Woropajewa „Dni powszednie w piekle”, „Szkice z dziejów obozów w Lamsdorf/Łambinowicach. Historia i współczesność”, z. 2, s. 150-179.

${ }^{8}$ Cf. P. S t a n e k, Przystanek Lamsdorf. Powstańcy warszawscy w obozie jenieckim Stalag 344, „Jeńcy Lamsdorf” t. I, Opole 2015; i d e m, Niewola powstańców warszawskich (1944-1945), „Dzieje Najnowsze" 2012, nr 2, s. 51-67. W czasie pierwszej wojny światowej przetrzymywano w obozie jenieckm Lamsdorf żołnierzy państw Ententy, głównie Rosjan (a wśród nich Polaków służących w armii carskiej), Rumunów, Serbów, Brytyjczyków, Francuzów - Bundesarchiv, Berlin-Lichterfelde, sygn. 901.84364, Politisches Archiv d. Auswärt. Amts. Akten betreffend das Gefangenenlager in Lamsdorf, m.in.: pismo z Kriegsministerium z 1 X 1917 r., Campamento de Lamsdorf dot. wizytacji z 9 I 1918 r., z 22 I 1918 r. dot. wizytacji przez dra Römera oddziału roboczego Cosel-Candau Chemiche Fabrik (Düngermittel), i stoczni Cäsar Wollheim, Cosel, obóz macierzysty: Lamsdorf, 7 I 1918 r., pismo Legation Royale Des Pays-Bas Section Britannique do Kaiserlich Auswärtiges Amt w Berlinie z 13 II $1918 \mathrm{r}$.

9 P. S t a n e k, Wniewoli..., s. 7-9; A. W i c k i e w i c z, op. cit., s. 69; W. P ó ł c h ł o p e k, Ucieczki z obozów jenieckich Lamsdorf (1944-1945), „Szkice z dziejów obozów w Lamsdorf/Łambinowicach. Historia i współczesność”, z. 2, s. 87-88, 94. Wspominali to sami jeńcy polscy. Vide: Centralne Muzeum Jeńców Wojennych [dalej: CMJW], Relacje i Wspomnienia [dalej: RiW], sygn. 9, Stanisław Sowierszenko; sygn. 29, 58, 59, Michał Basowski; sygn. 106, Józef Szajdzicki; sygn. 140, 
Hierarchia jeńców według traktowania ich przez władze obozowe



Źró dło: Zeszyt zadań do wystawy stałej „W niewoli niemieckiej”, oprac. A. Wickiewicz, B. Bezpałko, D. Musiał, P. Stanek, Opole 2012, s. 3; P. S t a n e k, W niewoli niemieckiej. Informator wystawy stałej Centralnego Muzeum Jeńców Wojennych w Lambinowicach-Opolu, Opole 2011, s. 9.

Zdolność do służby wojskowej, a właściwie wojennej została scharakteryzowana w niemieckich przepisach. Mężczyzna musiał być przydatny do każdego zajęcia i odznaczać się wytrzymałością i odpornością na wysiłek, niedostatek i warunki pogodowe, winien był temu sprostać zarówno pod względem fizycznym, jak i psychicznym. Jednakże w niektórych przypadkach przy słabszej budowie ciała wyrównanie stanowić mogły posiadane przez rekruta czynniki psychiczne, co zwłaszcza w przypadku ochotników mogło skutkować zakwalifikowaniem ich jako zdolnych do służby wojskowej. Można jeszcze wspomnieć o dwóch grupach

Mikołaj Panasiuk; sygn. 168, Piotr Czmyr. Uwidocznione to było także np. w przysługującej liczbie listów i kart pocztowych: Brytyjczykom przysługiwały cztery listy, a Polakom dwa, obie nacje miały prawo wysłać po dwie kartki pocztowe na miesiąc - Raport MKCK z wizytacji w Stalagu VIII B Lamsdorf z 17 VI 1941 r., CMJW, Materiały i Dokumenty [dalej: MiD], VIII Okręg Wojskowy, sygn. 111 . 
wyodrębnionych, ,g.v.F.” i „g.v.H.”, które oznaczały przydatnych bądź ewentualnie zdatnych do użycia na polu walki oraz w ojczyźnie, np. w ramach jednostek Strzelców Krajowych ${ }^{10}$. Strażnicy w Lamsdorf rekrutowali się zasadniczo spośród członków Batalionów Strzelców Krajowych - Landesschützen-Bataillone, np. $\operatorname{nr} 565,749^{11}$.

Strażników klasyfikowano według następującej hierarchii: inspektor ds. jeniectwa i dowódca w okręgu wojskowym (Wehrkreis, w przypadku Lamsdorf był to VIII Okręg Wojskowy), komendant obozu i oficerowie stalagu, komendant batalionu i oficerowie sztabu, dowódca kompanii, podoficer i oficer obserwacyjny, dowódca oddziału roboczego jeńców wojennych ${ }^{12}$. Oddelegowywani do stalagu Lamsdorf strażnicy rekrutowali się z różnych środowisk i grup. Istniała wymienność funkcji i częsta rotacja, która zabezpieczała w pewnym stopniu przed fraternizacją z jeńcami itp. zwłaszcza na terenach niejednorodnych etnicznie, jak Śląsk, z dużą liczbą Polaków, obywateli niemieckich, którzy byli powoływani do wojska. Powodem mogło być zastępstwo za chorego strażnika, jak miało to miejsce w przypadku ppor. Kerna, kierującego Stalagiem VIII F, który zastąpił w Stalagu VIII B chorego ppor. Niklitschka ${ }^{13}$. Tenże Niklitschek został później przeniesiony na stanowisko dowódcy plutonu do Landesschützen Bataillon

${ }^{10}$ http://voenspez.ru/index.php?topic=23128.0;wap2; http://vmg.vsbinfo.de/e/fehlertabelle.htm „Neufassung der ärztlichen Anweisung vom 12.08.1942 zur Beurteilung der Kriegsbrauchbarkeit bei Kriegsmusterungen" nach Rolf Valentin: Die Krankenbataillone; Schriftenreihe 2; Erfahrungen des deutschen Sanitätsdienstes im 2. Weltkrieg; Droste Verlag, Düsseldorf http://www.anhaltspunkte. de/vmg/e/fehlertabelle.htm. Szerzej: ibidem. Występowała kilkustopniowa klasyfikacja rekrutów niemieckich do służby pod względem zdrowotnym. Zasadniczo skale obowiązujące w czasie wojny i pokoju pokrywały się. Wyjątek stanowiły dwie pierwsze grupy A i B okresu pokoju, które na czas wojny trafiały do jednego koszyka pod wspólnym określeniem k.v., oznaczającym ,zdolny do wykorzystania w czasie wojny”. Znaleźli się tutaj ci, których przypadłości czy wady uznawane były za nieszkodliwe na tyle, że nie ograniczało to ich zdolności do służby wojskowej oraz ci, których warunkowo dopuszczano do niej. W dalszej kolejności, czyli w grupie Z lokowano tych, których wady i choroby czyniły co prawda czasowo niezdolnymi do służby, ale mogą zostać zmniejszone lub zlikwidowane i wówczas nastąpi ta zdolność. Stąd też na czas wojny zarezerwowano określenie z.u., czyli czasowo niezdolny. Grupa L obejmowała tych mężczyzn, których stan zdrowia zezwalał jedynie na ograniczoną służbę, co zasadniczo jednak nie przekreślało ich zdolności do pracy. W czasie wojny otrzymywali więc kategorię bed. k.v. jako warunkowo zdolni do służby wojskowej. Dwie ostatnie kategorie w czasie wojny: a.v. i w.u. odnosiły się do zaszeregowania w czasie pokoju w grupach U i vU. Przyznanie poborowemu ostatniej kategorii równało się w zasadzie z jego dyskwalifikacją, jeśli chodzi o mobilizację w czasie wojny, jako że oznaczała ona osobę niezdolną do służby wojskowej, a w czasie pokoju stanowiła brak zezwolenia na wykonywanie jakiejkolwiek użytecznej pracy (do celów wojskowych). Kategoria o szczebel wyżej zaś wyznaczała ludzi zdolnych do pracy, zarówno w czasie pokoju, jak i wojny, niedopuszczonych do służby wojskowej.

${ }^{11}$ J. S a w c z u k, S. S e n ft, op. cit., s. 133.

${ }^{12}$ Bundesarchiv-Militärarchiv Freiburg im Breisgau [dalej: Ba-Ma], Einrichtungen des Kriegsgefangenenwesens des Heeres, sygn. RH 49.207, Dienstanweisung für Wam, S. 2.

${ }_{13}$ Vojenský Ústřední Archiv, Praha [dalej: VUA], Stammlager VIII B 1939-1945, sygn. 213. 1.48, k. 17. 
$586 \mathrm{Breslau}^{14}$. Analogiczna sytuacja, tj. wysłanie w maju 1942 r. ze Stalagu VIII F do VIII B jako kierownika wartowników (P.Ü. Post Überwachtung) dotyczyła kpt. dr. Rolanda Martina, który trafił następnie we wrześniu 1942 r. do Dulagu 375 Szablino w północnej Rosji jako oficer wywiadu (A.O. Abwehroffizier $)^{15}$.

Dowództwo Sił Zbrojnych III Rzeszy (Oberkommando der Wehrmacht, OKW) zwracało uwagę na kształtowanie relacji żołnierzy niemieckich z jeńcami. W tym celu wydawane były różnego rodzaju pouczenia i regulaminy. Jednym z nich była instrukcja Naczelnego Dowódcy Wehrmachtu Szefa Zarządu Wojskowego we Francji z 13 sierpnia 1940 r. skierowana do niemieckich żołnierzy, w której czytamy: ,jeńcy wojenni byli naszymi [tj. Niemców - E.K.] wrogami ${ }^{16}$, a wielu $z$ naszych towarzyszy przez nich straciło życie, jak również wielu z nich zostało haniebnie potraktowanych $w$ niewoli ${ }^{17}$ ". Stąd wysnuwano dalsze wnioski: słabością miało być prowadzenie relacji z jeńcami, zwłaszcza koleżeńskich. Podobnie kontakt/styczność jeńców z ludnością cywilną uznawano za zakazany. Wobec tego należało zachowywać dystans ${ }^{18}$ wobec nich, zarówno w trakcie marszu do pracy, jak i podczas nadzoru/eskorty przy pracy. Niemieckiemu żołnierzowi nie wolno było dręczyć, znęcać się nad jeńcami, jednak miał prawo do użycia broni, jeśli wymagała tego konieczność. Żołnierz powinien mieć na uwadze, że przez swoją „czułostkowość” wspiera jedynie zdradę - pouczano ich. Jego surowe zachowanie - przekonywano zatem - powodowałoby zdyscyplinowanie jeńców, od których należało wymagać dla siebie szacunku i najostrzejszej dyscypliny. Ponadto podkreślano, że jeńcy muszą pracować, co uznawano za ich naturalny obowiązek, od którego nie należało ich zwalniać. Wskazywano przy tym, że dobowy czas pracy jeńców winien wynosić przynajmniej 8 godzin ${ }^{19}$.

Strażnicy byli pouczani o ich roli i obowiązkach, m.in. że są przełożonymi jeńców i wszelkie polecenia, jakie wydają w ramach pełnienia swojej służby, muszą być bezwarunkowo wykonywane, także przez osoby cywilne, a nawet innych

${ }^{14}$ Ibidem, k. 23. Informację taką znajdujemy trzy miesiące po rozkazie o zastąpieniu go w stalagu Lamsdorf z uwagi na chorobę.

15 Ibidem, k. 27-28, 36, http://www.lexikon-der-wehrmacht.de/Gliederungen/Kriegsgefange nenlager/Dulag.htm (dostęp: 18 XII 2017).

${ }_{16}$ Podobnie pisano o Polakach i czerwonoarmistach - „Bolszewizm jest śmiertelnym wrogiem narodowosocjalistycznych Niemiec”, cyt. za: W. P ółc hło p e k, op. cit., s. 87; „[...] jeńcy pozostają naszymi wrogami. Należy ich traktować surowo i sprawiedliwie. Należy wymagać od nich wojskowej postawy" - cyt. za: J. S a w c z u k, S. S e n ft, op. cit., s. 172.

${ }^{17}$ Ba-Ma, Einrichtungen des Kriegsgefangenenwesens des Heeres, sygn. RH 49.175 Stalag 121 Epinal Gruppe Verwaltung Abteilung Lohnabrechnung, Merkblatt von dem Oberbefehlshaber des Heeres. Des Chefs der Militärverwaltung in Frankreich, Paryż 13 VIII 1940.

${ }^{18} \mathrm{O}$ tym, że strażników i jeńców miały łączyć jedynie stosunki służbowe (nawet te należało ograniczać do niezbędnie koniecznych), a wszelkie inne były zabronione, mówiło Rozporządzenie o obchodzeniu się z jeńcami wojennymi, wydane 11 maja 1940 r. przez H. Himmlera - Ba-Ma, Einrichtungen des Kriegsgefangenenwesens des Heeres, sygn. RH 49.207, Dienstanweisung für Wam, s. 31.

${ }^{19} \mathrm{Ba}-\mathrm{Ma}$, Einrichtungen des Kriegsgefangenenwesens des Heeres, sygn. RH 49.175 Stalag 121 Epinal... 
niemieckich żołnierzy, jeśli zarządzenia te są niezbędne dla eskorty jeńców. Wszelkie kontakty jeńców z cywilami i żołnierzami, którym nie powierzono pilnowania ich, uznawano za konieczne do wyeliminowania. Wstęp jeńców do zamkniętych pomieszczeń bądź na zabudowane działki był dozwolony tylko, gdy było to związane z poleceniem służbowym strażnika. W przypadku każdej próby ucieczki ${ }^{20}$ podjętej przez jeńca strażnikom wolno było użyć broni bez ostrzeżenia. Wszelkie transakcje wymiany oraz przyjmowanie od jeńców prezentów były zabronione. Jakikolwiek stosunek pozasłużbowy (np. rozmowa) pomiędzy strażnikami a jeńcami był niedozwolony. Zabroniono jeńcom również wstępu do restauracji i sklepów ${ }^{21}$. Ażeby wyeliminować czy zwalczać nieposłuszeństwo wśród jeńców, strażnikom wolno było używać broni do bicia, np. kolby karabinu czy bagnetu. Jeśli nie przyniosło to efektu, owych krnąbrnych jeńców karano aresztem. W przypadku napaści czy zaczepki ze strony jeńca strażnik miał prawo użyć broni ${ }^{22}$.

$\mathrm{W}$ opinii niemieckich mocodawców z urzędu ds. jenieckich jeńców należało traktować surowo, ale sprawiedliwie. Zgodnie z konwencją genewską z $1929 \mathrm{r}$. żołnierze w niewoli powinni być traktowani tak samo, bez względu na narodowość czy przynależność państwową. W praktyce jednak jeńcy z krajów zachodnich byli traktowani lepiej niż np. Polacy, których z kolei traktowano lepiej niż żołnierzy sowieckich (zob. diagram). Fakt niestosowania wobec byłych żołnierzy Armii Czerwonej zasad konwencji genewskiej Niemcy thumaczyli niepodpisaniem jej przez ZSRR ${ }^{23}$. Było to jednak thumaczenie niezasadne, gdyż z faktu sygnowania konwencji przez państwo niemieckie wynikały dla nich obowiązki należytego traktowania jeńców państw innych, niezależnie od tego czy ich państwo macierzyste było sygnatariuszem konwencji ${ }^{24}$. Ponadto zalecano niemieckim żołnierzom unikanie zażyłości/poufałości z żołnierzami pokonanej armii przeciwnika. Warto zauważyć, że jeńcom nie wolno było używać niemieckich pozdrowień. Rozmowy strażników z jeńcami winny być prowadzone jedynie w zakresie obowiązków

${ }^{20}$ Niektórzy dowódcy niemieccy twierdzili, jak np. komendant Oflagu II D Gross Born płk Loebbecke, że „ucieczka jest dobrym prawem jeńca. Wy jesteście po to, żeby uciekać, a my po to, żeby was pilnować" - cyt. za: S. D a t n e r, Ucieczki z niewoli niemieckiej 1939-1945, Warszawa 1966, s. $54-55$.

${ }^{21}$ Ba-Ma, Einrichtungen des Kriegsgefangenenwesens des Heeres, sygn. RH 49.175, Allgemeine Dienstanweisung für Wachmannschaften.

${ }^{22}$ Ibidem, sygn. RH 49.207, Dienstanweisung für Wam, s. 13-14.

${ }^{23}$ Dobitnym przykładem nieprzestrzegania konwencji był przede wszystkim los jeńców z Armii Czerwonej, ale także niekiedy z państw zachodnich. Jeńcy sowieccy na ziemiach polskich $w$ czasie II wojny światowej, red. J. Wojtkowiak, Warszawa 2015; P. S tan e k, Jeńcy w kajdanach: casus uczestników rajdu na Dieppe, „Przegląd Historyczny” 2014, t. CV, nr 4, s. 633-643. Na przykład surowe rozkazy dotyczące poszukiwania i rozstrzeliwania zbiegłych jeńców sowieckich wykonywano sumiennie. W. Półchłope k, op. cit., s. 88-89.

${ }^{24}$ „W razie, gdyby w czasie wojny jedna ze stron wojujących nie należała do konwencji - jej postanowienia będą pomimo to obowiązujące dla stron wojujących, które do niej należą", art. 82 Konwencji, Dz. U. RP z 1932, nr 103, poz. 866. Szerzej: M. F 1 e m m ing, Jeńcy wojenni. Studium prawno-historyczne, Warszawa 2000. 
służbowych. Zabraniano także pozowania do wspólnych zdjęć, miało to bowiem uwłaczać godności niemieckiego żołnierza, a naruszający ten przepis podlegali karze. Nie dotyczyło to oczywiście fotografii tworzonych przez Niemców w celach propagandowych, jak też zdjęć prywatnych, ukazujących np. stosunki panujące w obozie czy jego wygląd itd. Niemniej w przypadku zakazu wspólnego fotografowania się należy dopatrywać się obawy dowódców przed fraternizacją ${ }^{25}$ czy choćby na pozór nic nie znaczącym omijaniem reguł, a więc zbliżaniem się, budowaniem poufałości z jeńcami ${ }^{26}$.

Można odwoływać się do relacji przesłuchiwanych współpracowników czy przetrzymywanych. Wówczas da się uzyskać pewną dozę informacji obiektywnych, ale i sporą garść odczuć subiektywnych, przemieszanych z domysłami, niejasnościami, a czasem wręcz zwykłymi plotkami. W przypadku stalagu Lamsdorf dysponujemy pewną liczbą spisanych protokołów przesłuchań, z których jednakże wynika słaba i wyrywkowa znajomość dokładnych danych personalnych interesujących nas członków załogi. Natomiast dość często pojawiają się wzmianki dotyczące wyglądu żołnierzy. Jeńcy z reguły nie znali dokładnych danych personalnych strażników. Pamiętali co najwyżej ich imiona lub nazwiska, przezwiska, potrafili opisać jak wyglądali. Dodajmy, że również liczba osób określanych jako znajome była ograniczona, a więc informacje od poszczególnych osób będą stanowić jedynie wycinek całości ${ }^{27}$.

${ }^{25}$ Zdarzały się przecież tego typu przypadki. Wystarczy wspomnieć kilka z nich, np. w obozie dla oficerów polskich Oflagu II D Gross Born (obecnie Borne Sulinowo) istniała współpraca między tamtejszym strażnikiem Ernstem Heimem a Polakami, głównie z por. Maksymilianem Kreutzingerem, a także z Kazimierzem Milejem. Wspierał on polską konspirację poprzez dostarczanie odpowiednich danych, map, broni. Miał także wspomagać ich w razie ucieczki, np. poprzez udostępnienie im miejsc schronienia. Karą za takie postępowanie niemieckiego strażnika, motywowanego wszakże prawdopodobnym jego polskim pochodzeniem (matka z Mazur), był wyrok śmierci. T. Skow ron ek, Wbrew regulaminowi. Wspótpraca Maksymiliana Kreutzingera z Ernestem Heimem w Oflagu II D Gross Born, [w:] Zwykty żotnierski los. Jeńcy wojenni na Pomorzu Zachodnim (1939-1945), red. J. Aniszewska, R. Kobylarz-Buła, P. Stanek, Opole 2011, s. 179-192; M. Sadzewicz, Oflag II D Gross Born, Warszawa 1977, s. 118-119. Przypadków takich było więcej. Przykładowo: Leżący w szpitalu jeniec Jan Frydrychowski dzięki przychylności strażnika, pielęgniarza (z Kaszub) miał możliwość zobaczenia się z rodziną - żoną i synem. Było to w końcowym okresie wojny (wiosna 1944 r.). Vide: M. Frydrychow ski, Wspomnienie o Ojcu Janie Frydrychowskim, jeńcu oflagów II B Arnswalde i II D Gross Born, „Łambinowicki Rocznik Muzealny" 2015, t. XXXVIII, s. 143-145. Z polskimi jeńcami współpracował także niemiecki sanitariusz polskiego pochodzenia, Roger Virion, zwłaszcza podczas organizowanej tajnej jenieckiej olimpiady w Stalagu XIII A Nürnberg-Langwasser w 1940 r. Vide: W. Półchłopek, Igrzyska olimpijskie w obozach jenieckich (1940 i 1944), „,Lambinowicki Rocznik Muzealny” 1996, t. XIX, s. 21-22. Także mjr dr Rettinger, lekarz w Oflagu II D Gross Born przekazał jeńcom broń. M. S a d z e w i c z, op. cit., s. 119.

${ }^{26}$ Ba-Ma, Einrichtungen des Kriegsgefangenenwesens des Heeres, sygn. RH 49.207, Dienstanweisung für Wam, S. 12-13.

${ }^{27}$ Są to przesłuchania świadków przed komisjami: komisją polsko-radziecką dla badania niemieckich zbrodni wojennych ze stycznia 1946 r., komisjami Okręgowych Komisji Badania 
Strażnikom wolno było wychodzić co najmniej we dwóch. W niedzielę odbywali służbę wszyscy żołnierze bez wyjątku. Obejmowało to wówczas wykład dotyczący NSDAP. Podczas późniejszego apelu podoficerowie i szeregowi winni być ubrani w mundury, czapki polowe, płaszcze i ochraniacze (buty). Wymagane było wówczas posiadanie przy sobie broni, natomiast maski gazowe nie były już niezbędnym elementem wyposażenia ${ }^{28}$. Przepisy te (w sprawie posiadania broni w ciemności i przemieszczania się we dwóch) dotyczyły także oficerów. Za ich nieprzestrzeganie groziła surowa $\mathrm{kara}^{29}$. Cotygodniowe szkolenia, na które żołnierze winni się stawić również z maskami gazowymi, odbywały się z przerwami od godzin porannych do wieczornych. Wśród zajęć znajdowało się np. śpiewanie, czyszczenie broni, czyszczenie i reperowanie odzieży i obuwia, apel z bronią ${ }^{30}$. Prowadzono również wielogodzinne wykłady merytoryczne: teoretyczne i praktyczne, np. kurs na temat obrony przeciwgazowej dla wszystkich pracowników umysłowych i robotników obojga płcisi.

Do obowiązków strażników należało ponadto zapobieganie kontaktom jeńców z ludnością cywilną, zarówno niemiecką, jak i nieniemiecką. Szczególnie surowo zabronione było zbliżanie się i nawiązywanie relacji z niemieckimi kobietami i dziewczętami ${ }^{32}$. Za złamanie tego zakazu groziło 10 lat więzienia lub nawet śmierć ${ }^{33}$.

Strażnicy służyli w różnych miejscach, pilnując jeńców wojennych wykonujących prace poza terenem obozu: w zakładach, w rolnictwie, na rzecz władz lokalnych (burmistrz, urząd pracy, żandarmeria). Głównym ich zadaniem miało być rygorystyczne pilnowanie jeńców oraz baczna obserwacja, tak, by rozpoznać na czas zamierzoną próbę ucieczki ${ }^{34}$ oraz zapobiegać odmowom wykonywania pracy, buntom i sabotażom. Prowodyrów takich działań należało rozpoznawać wcześnie

Zbrodni Hitlerowskich z lat 60. XX w., np. Opole, Białystok, Prokuratury Wojskowej Północnej Grupy Wojsk z grudnia 1945 r. i stycznia 1946 r., Powiatowego Urzędu Bezpieczeństwa w Niemodlinie z grudnia 1945 r. Świadkowie to m.in. byli jeńcy czy pracownicy z personelu obozu. CMJW, MID, VIII OW, sygn. 6, passim.

${ }^{28}$ VUA, Stammlager VIII B 1939-1945, sygn. 24.3.4, Kompaniebefehl z 4 XI 1944 r.

${ }^{29}$ Ibidem, Standortbefehl Nr. 37 z 1 XI 1944 r.

${ }^{30}$ Ibidem, Kompaniebefehl z 17 V 1944 r., 30 IX 1944 r., 7 X 1944 r., 14 X 1944 r.

${ }^{31}$ Ibidem, Kommandanturbefehl Nr. 12 z 15 V 1944 r.

${ }^{32} \mathrm{Za}$ te wykroczenia, tzw. przestępstwa przeciwko rasie karani byli także obywatele niemieccy, jeńcy często za tego typu przestępstwa ginęli w karnych egzekucjach. Jednakże także w przypadku tego rodzaju przestępstw strażnicy z obozu Lamsdorf mieli swój udział poprzez zezwalanie jeńcom na kontakty z Niemkami. J. B a n ik, R. K o by lar z, „,...Podeptali godność narodu niemieckiego”. Rassenschande w rejencji opolskiej (1939-1945), „Studia Śląskie” 2007, t. LXVI, s. 39-57.

33 Ba-Ma, Einrichtungen des Kriegsgefangenenwesens des Heeres, sygn. RH 49.207, Dienstanweisung für Wam, s. 13.

${ }^{34}$ Zdarzały się jednak częste doniesienia o ucieczkach ze stalagu Lamsdorf, co mogło świadczyć nie tylko o determinacji jeńców, ale i o niekompetencji strażników, ich niesubordynacji bądź zbyt małej liczbie. W. Półchłope k, Ucieczki..., s. 91. 
i meldować o tym przełożonym. Strażnik powinien mieć przy sobie broń ${ }^{35}$ gotową do strzału, a poza służbą - w zasięgu ręki. Jako broń może mu służyć pistolet, karabin, lecz nie śrutówka (Schrotflinte). Wartownik winien się także odznaczać specjalną opaską, którą wraz z bronią musiał stale nosić podczas służby. Strażnicy pełniący służbę pomocniczo, zmobilizowani z konieczności, wojskowo podlegali komendantowi, natomiast dyscyplinarnie władzom cywilnym. Zalecano, aby szczególnie skrupulatnie pełnić straż w dni świąteczne i niedziele. Co ciekawe, określano nie tylko konieczność zamieszkiwania w bliskiej odległości strażników od jeńców, ale także uszczegóławiano wyposażenie obiektu mieszkalnego strażnika i stan jego czystości ${ }^{36}$. Inną kwestią jest to, jak często udawało się wypełnić te drobiazgowe przepisy.

Władze obozowe przywiązywały dużą wagę do utrzymania wysokiego morale i wzajemnych dobrych relacji między strażnikami. Naruszanie tych norm karano. Przykładem może być sprawa plutonowego Edwina Süßera, skazanego na trzy dni łagodnego aresztu za obrazę podwładnego, którego miał nazwać zbrodniarzem wojennym, ,pól-żołnierzem” i dziwną figurą ${ }^{37}$. Karano również za jakiekolwiek naruszenie drobiazgowych procedur postępowania. Fritza Moentinga ukarano naganą oraz czternastoma dniami zaostrzonego aresztu za samowolne opuszczenie lazaretu $^{38}$. Natomiast Richard Schipke skazany został na trzy dni lekkiego aresztu za to, że nie przestrzegał drogi służbowej podczas starania się o urlop ${ }^{39}$. Alfred Jerauschek 25 lutego 1944 r. otrzymał surową naganę od dowódcy von Weberna za naruszenie warunków służby, gdyż na krótki urlop udał się dzień wcześniej ${ }^{40}$. Z kolei Ignatz Dudek 25 czerwca 1943 r. został ukarany trzema dniami łagodnego aresztu oraz dwutygodniowym ograniczeniem w przepustkach za nawiązanie bliskiej relacji z kobietą, napisanie listu miłosnego w imieniu oficera, przez co zaszkodził opinii niemieckiego korpusu oficerskiego ${ }^{41}$.

Jak już wspomniano, jednym z podstawowych zadań strażników było zapobieganie $^{42}$ ucieczkom jeńców. Służyć temu miało odpowiednie przygotowanie pomieszczeń, w których byli oni zakwaterowani. Zwracano uwagę na zabezpieczenia

${ }^{35}$ Strażnikom, którzy zwlekali z użyciem broni w przypadku ucieczki jeńca sowieckiego, groziły represje, a nawet sąd wojenny. Zauważana jest tu dysproporcja w traktowaniu poszczególnych grup jenieckich, gdyż jeńców Armii Czerwonej dozwolone, a nawet zalecane było strzelanie bez ostrzeżenia, nawet celem zabicia, a nie tylko zranienia. W. Półchło p ek, Ucieczki..., s. 88, 94-95.

${ }^{36}$ Ba-Ma, Einrichtungen des Kriegsgefangenenwesens des Heeres, sygn. RH 49.207, Dienstanweisung für Wam, s. 1, 4-6.

${ }^{37}$ VUA, Stammlager VIII B 1939-1945, sygn. 45.1.20, Stlag VIII B. Erstes Strafbuch für Unteroffiziere, k. 24.

${ }^{38}$ Ibidem, k. 10.

39 Ibidem, k. 9.

${ }^{40}$ Ibidem, k. 23.

${ }^{41}$ Ibidem, k. 28.

${ }^{42}$ O konieczności zachowania dyscypliny wśród jeńców, zapobiegania ucieczkom i wykorzystaniu broni palnej vide: W. Półchłope k, Ucieczki..., s. 87. 
drzwi i okien (np. drzwi miały być mocno zbudowane, zwracano uwagę na zawiasy, drzwi podparte żelazną listwą lub drewnem z zewnątrz, okna zaś żelaznymi prętami lub drewnem), aczkolwiek pozostawiano niewielką możliwość otwierania okien celem wentylacji. Z kolei dla zapobiegania pożarom w pomieszczeniach miały stać kubły z wodą, było to ważne ze względu np. na słomiane sienniki. Zabraniano również rozrzucania słomy po obozie. Strażnikom nie wolno było palić papierosów w pomieszczeniach narażonych na działanie ognia, a przed udaniem się na spoczynek zobowiązani byli sprawdzić czy wszystkie miejsca, w tym drzwi i okna, są mocno/dokładnie zamknięte, światło zgaszone, a w piecach nie pali się ogieńn ${ }^{43}$.

Przytoczone wyżej zarządzenia jasno określały obowiązki i normy zachowań strażników w stosunku do jeńców. W praktyce jednak żołnierze nie zawsze należycie przestrzegali obowiązujących ich regulaminów. W dokumentach Stalagu VIII B Lamsdorf znajdujemy liczne wzmianki o tym, np. dane z przesłuchań (gdy jeńcy uciekli, to przesłuchiwano odpowiedzialnych za ich eskortę strażników), np. st. szer. st. szer. Kühnast, Tofaute i Güldenpfennig 14 maja 1943 r. nadzorowali jeńców angielskich podczas budowy łaźni. Po zakończeniu prac zbiegło dwóch brytyjskich jeńców. Stało się tak, ponieważ strażnicy skupili się na poszukiwaniach i zbieraniu narzędzi pracy, zaniedbując tym samym nadzór nad jeńcami ${ }^{44}$.

W innym przypadku była mowa o niewłaściwym zarządzaniu nadzorem. Było tak w przypadku szer. Richlikowskyego i pomagającego mu szer. Harlebena, którzy nadzorowali pracę 20 jeńców brytyjskich w lesie 14 maja 1943 r. Z oczywistych względów las nie zapewniał dostatecznej widoczności, zaś słaby słuch i wzrok Harlebena pogłębiał tylko istniejącą sytuację. Do prac w lesie należało przeznaczać większą liczbę strażników ${ }^{45}$. Winni niedbałego wykonywania służby zostali ukarani: Kühnast Richlikowsky i Harleben - naganą, Tofaute i Güldenpfennig - trzema dniami zaostrzonego aresztu ${ }^{46}$.

Zdarzały się także bardzo pozytywne opinie przełożonych o podwładnych, co w przypadku późniejszego niedopełnienia obowiązków strażniczych przekładało się na mniej surową karę. Dowodem jest choćby przypadek np. thumacza sierż. Franza Krönesa, którego opisywano jako m.in. uczciwego, pracowitego, uczynnego, obowiązkowego, odpowiedzialnego. W Wehrmachcie służył od lutego 1942 r., od stycznia 1944 r. jako thumacz w stalagu Lamsdorf, wiadomo o nim, że nie był członkiem partii nazistowskiej, odnotowano też fakt, że w cywilu nie był karany.

${ }^{43}$ Ba-Ma, Einrichtungen des Kriegsgefangenenwesens des Heeres, sygn. RH 49.207, Dienstanweisung für Wam, s. 6-7.

44 VUA, Stammlager VIII B 1939-1945, sygn. 243.1.52, Vernehmigungsniederschrift z 15 V 1943 r. Podobne sytuacje zdarzały się w oddziałach roboczych. Vide: W. Pół c hło p e k, Ucieczki..., s. 95 .

${ }^{45}$ VUA, Stammlager VIII B 1939-1945, sygn. 243.1.52, Vernehmigungsniederschrift z 15 V $1943 \mathrm{r}$.

${ }^{46}$ Ibidem, pismo z 18 V 1943 r. i Aufahme in den Batls. Befehl. 
Jego przydatność do służby została określona mianem k.v. Wcześniej zajmował się umysłowo chorymi. Podobnie st. szer. Emil Moraw, pełniący służbę w Wehrmachcie od września 1942 r., a od sierpnia 1944 r. w stalagu Lamsdorf. Był bezpartyjny, niekarany, a jego wykształcenie określono jako: techniczny pracownik umysłowy. Gdy pewnego razu obaj eskortowali trzech jeńców wojennych, jeden $\mathrm{z}$ nich (Polak) zniknął w thumie podczas wysiadania $\mathrm{z}$ pociągu. Broniąc się przed odpowiedzialnością za tę ucieczkę podczas przesłuchań strażnicy składali jednak wzajemnie sprzeczne zeznania, jak do tego doszło. Rozbieżności dotyczyły np. kolejności ustawienia się strażników podczas przemarszu z jeńcami na stacji czy informacji, który ze strażników pytał osoby postronne o kolejny pociąg. Analiza wyjaśnień strażników oraz dwóch pozostałych jeńców: Rumuna i czerwonoarmisty pozwoliły ustalić winnego - Krönesa. Przełożeni uznali, że pełniąc służbę dopuścił się zaniedbań, które umożliwiły wymknięcie się powierzonego mu jeńca. W związku z tym ukarali go 5-dniowym zaostrzonym aresztem. Karę tę uznano za wystarczającą z uwagi na dotychczasowy przebieg jego służby: był niekarany, usłużny, sumienny. Za okoliczności łagodzące uznano ponadto: tłok, ciemność, cywilne ubranie jeńca ${ }^{47}$.

Karano również strażników za jakąkolwiek próbę przekupstwa czy przyjmowania darów, łapówek itp. Przykładowo: szer. Hans Gersitz został ukarany tygodniowym zaostrzonym aresztem za przyjęcie 2 paczek papierosów od jeńca brytyjskiego podczas warty w stalagu 19 maja 1943 r., a następnie próbował kwestionować to zajście w sposób uznany za nieżołnierski. W zeznaniach podał, że w czasie szkolenia został poinstruowany, że „każde pozasłużbowe stosunki z jeńcami, w szczególności przyjmowanie prezentów i przedsiębranie działalności wymiennej są surowe zabronione", a mimo to złamał ten przepis, ponadto okłamał swego przełożonego, pytającego o pochodzenie papierosów ${ }^{48}$.

Zdarzało się, że niektórzy strażnicy okazywali jeńcom przychylność w przypadku, np. śląskich rezerwistów (m.in. Paweł Hauk, podoficer Ledwolerz, niejaki „dr Lei”, Jan Lisoń, Röll, kpt. Wróbel vel Schauller, którym zarzucano nadmierną życzliwość wobec jeńców polskich) ${ }^{49}$. Z kolei plut. Stefan Skowroński dostał paczuszkę żywnościową od jednego z niemieckich podoficerów ${ }^{50}$. Niektórzy jeńcy wykonywali nawet zabawki dla dzieci strażników, za co otrzymywali od nich trochę chleba ${ }^{51}$.

47 Ibidem, sygn. 45.1.20, Verhandlung Krönes i Moraw Teschen, z 2 I 1945 r. rv, Beurteilung, Teschen O/S z 5 I 1945 r., Vernehmungsniederschrift Bogdananu Leonard i Sterlingow Alexander, Teschen, z 2 I 1945 r., pismo do Teschen, do Kommandantur des Kriegsgefangenenswesen im Wehrkreis VIII Breslau, z 7 I 1945 r. rv.

${ }^{48}$ Ibidem, sygn. 243.1.52, pismo z 21 V 1943 r.; zeznanie szer. Hansa Gersitza z 19 V 1943 r.

${ }^{49}$ CMJW, RiW, sygn. 38, Piotr Bogacki. Niektórzy jeńcy przedstawiali odwrotne opinie o Ślązakach jako bardzo złych. CMJW, RiW, sygn. 1251, Zdzisław Wasylenki; sygn. 240, Stanisław Pozusiński.

${ }^{50}$ CMJW, Muzealia, nr inw. CMJW II-1-441, Dziennik Stefana Skowrońskiego, zapis z 14 XII $1939 \mathrm{r}$.

${ }^{51}$ CMJW, RiW, sygn. 34, Alfons Jedlicki; MiD VIII OW, sygn. 6, Świadek Jan Mróz. 
Warto przytoczyć przykład Gustawa Würtha, który karany był za naganne zachowania w czasie służby w Wehrmachcie, ale też i poza nią. Za zakazany kontakt $\mathrm{z}$ jeńcami został mu wymierzony zaostrzony areszt czterotygodniowy, do którego to okresu wliczono tygodniowe pozbawienie wolności. Co ciekawe był on karany prawdopodobnie jako cywil w 1934 r., kiedy spędził 5 miesięcy w więzieniu za próbę gwałtu. Wiadomo też, że od lutego 1936 r. do stycznia 1937 r. znajdował się w obozie koncentracyjnym Dachau. Była to kara za to, że w 1934 r. otrzymał od byłego działacza SPD nielegalne czasopisma i zaniechał złożyć doniesienia w tej sprawie ${ }^{52}$.

Kapral Karl Geisler - będący w służbie od czerwca 1941 r. - 8 kwietnia 1943 r. dokonał transakcji wymiany: chleb - mydło z jeńcem brytyjskim ${ }^{53}$. Z kolei starszy kapral Hans Wondraczek 5 czerwca 1943 r. miał dopuścić się zdrady tajemnicy wojskowej i wystąpienia przeciwko swoim obowiązkom żołnierskim. Spoufalał się z jeńcami, utrzymywał z nimi kontakt, był im przychylny, przestrzegał przed prawdopodobnymi agentami gestapo. Wskazywano na jego prawdopodobnie niemoralne zachowanie w kwestiach damsko-męskich ${ }^{54}$.

Karano również strażników za pospolite kradzieże, np. st. sierż. Ernst Janowsky za kradzież wojskową został ukarany 4-miesięcznym więzieniem oraz utratą stopnia wojskowego ${ }^{55}$. Prawdopodobnie chodzi o złamanie paragrafu 138 ust. 1 kodeksu karnego wojskowego, w którym czytamy: „Kto podczas wykonywania służby lub z naruszeniem wojskowych stosunków służbowych jest winny popełnienia kradzieży bądź przywłaszczenia rzeczy, jakie były mu powierzone lub dostępne podczas służby, podlega karze średniego albo ciężkiego aresztu nie krócej niż 14 dni czy też więzienia do lat 5, jednocześnie może zostać pozbawiony obywatelskich praw honorowych. Taka sama kara dotyczy tego, kto dopuszcza się kradzieży bądź sprzeniewierzenia przeciwko zwierzchnikowi lub kolegom, jego gospodarzowi kwatery lub należącej do tego gospodarstwa domowego osobie" 56 .

Polacy we wspomnieniach przywoływali liczne przykłady złego traktowania ich przez strażników (w odniesieniu do niemieckiego personelu obozu jeńcy przede wszystkim mieli do czynienia z wachmanami, strażnikami), np., że podczas rozdzielania żywności byli przez nich bici ${ }^{57}$. W ogóle wachlarz kar za rozmaite wykroczenia jeńców był szeroki ${ }^{58}$. W dodatku surowa postawa strażników

${ }^{52}$ VUA, Stammlager VIII B 1939-1945, sygn. 45.1.20, Stalag VIII B. Erstes Strafbuch für Unteroffiziere, k. 15.

${ }^{53}$ Ibidem, sygn. 243.1.52, Załącznik do pisma do komendanta Stalagu VIII B Abt. I c (A.O.), Lamsdorf z 19 V 1943 r.

${ }^{54}$ Ibidem, pisma do komendanta Stalagu VIII B Abt. I c (A.O.), Lamsdorf z 7 VI 1943 r. rv.

${ }_{55}$ Ibidem, sygn. 45.1.20, Stalag VIII B. Erstes Strafbuch..., k. 25. Kara miała trwać od 24 V 1944 r. do 23 IX 1944 r.

${ }^{56} \mathrm{http}: / / w w w . d o c u m e n t a r c h i v . d e / k s r / 1872 /$ militaerstrafgesetzbuch_deutsches-reich.html (dostęp: 15 I 2018).

${ }^{57}$ CMJW, RiW, sygn. 40, Mikołaj Moliński.

${ }^{58}$ Ibidem, sygn. 486, Jan Waldun; sygn. 564, Henryk Butyński. 
wobec jeńców wynikała także $\mathrm{z}$ obserwacji postawy przełożonych - przykład szedł z góry. Jeden z komendantów obozu - dr ppłk Borneman okazywał szczególną wrogość w stosunku do jeńców ${ }^{59}$.

Służbę strażników w obozie Lamsdorf, jak i w innych obozach jenieckich Wehrmachtu normowały regulaminy, szczegółowo określające zakres obowiązków oraz zasady zachowania. Jednakże sposób, w jaki strażnicy wywiązywali się ze swych powinności, niejednokrotnie odbiegał od wytycznych zawartych w rozporządzeniach wydawanych przez zwierzchników. Odzwierciedlenie znajduje się w niemieckich dokumentach dotyczących karania strażników za nieprzestrzeganie regulaminu oraz w relacjach i wspomnieniach jenieckich.

Monotonia służby, chęć zdobycia deficytowych towarów czy wręcz dążenie do poprawy sytuacji materialnej skłaniały żołnierzy do łamania praw, którym podlegali. Problemy strażników z prawem i regulaminami są tematem dosyć istotnym, bo przekładały się m.in. na stosunek do jeńców i ich traktowanie. Warto zaznaczyć, że wśród osób kierowanych do służby w obozach były i takie, które już wcześniej popadały w konflikt z prawem. Można dostrzec szereg przykładów naruszania przepisów przez żołnierzy niemieckich, zarówno w związku ze służbą w stalagu, jak i poza nim. Z pewnością wielu strażników nie zasługiwało na miano wzorowych żołnierzy.

Natomiast nieprzestrzeganie regulaminu poprzez kontaktowanie się z jeńcami to szczególny przypadek łamania dychotomii my kontra oni, a przecież strażnicy i jeńcy byli jako wrogowie po przeciwnej stronie barykady, jako uczestnicy działań wojennych, a także w sytuacji izolacji jeńców w obozach jenieckich.

Regulaminy normowały szczegółowo obowiązki strażników. Zabronione były zwłaszcza prywatne kontakty między strażnikami a jeńcami. Jednak strażnicy łamali te zakazy, dokonując np. transakcji wymiennych. Innym poważnym wykroczeniem była nieostrożność, niedopilnowanie jeńców, co skutkowało ucieczkami.

Należy pamiętać, że pomimo przypadków, w których strażnicy okazywali się bardziej ludzcy w stosunku do podległych im jeńców, pozostawali oni w dalszym ciągu ich przeciwnikami, traktując ich nie tylko z regulaminową surowością, lecz także z pozaregulaminowym okrucieństwem.

\section{Bibliografia}

\section{ŹRÓDLA ARCHIWALNE}

Bundesarchiv Berlin-Lichterfelde

sygn. 901.84364.

Bundesarchiv-Militärarchiv Freiburg im Breisgau [Ba-Ma]

${ }^{59}$ Ibidem, sygn. 1009, Bronisław Cwynar; sygn. 199, Mikołaj Honczar. 
Einrichtungen des Kriegsgefangenenwesens des Heeres, sygn. RH 49.175, RH 49.207.

Centralne Muzeum Jeńców Wojennych [CMJW]

Materiały i Dokumenty [MiD], VIII Okręg Wojskowy, sygn. 6, 111.

Muzealia, nr inw. CMJW II-1-441.

Relacje i Wspomnienia [RiW], sygn. 9, 29, 34, 38, 40, 58, 59, 106, 140, 168, 199, 240, 486, 564, $1009,1251$.

Vojenský Ústředni Archiv, Praha [VUA]

Stammlager VIII B 1939-1945, sygn. 24.3.4, 45.1.20, 213.1.48, 243.1.52.

\section{ŹRÓDEA DRUKOWANE}

Dz. U. RP z 1932, nr 103, poz. 866.

Dziennik jeńca wojennego Siergieja Woropajewa „Dni powszednie w piekle”, „Szkice z dziejów obozów w Lamsdorf/Łambinowicach. Historia i współczesność”, z. 2, red. E. Nowak, Opole 2000, s. $150-179$.

Frydrychowski M., Wspomnienie o Ojcu Janie Frydrychowskim, jeńcu oflagów II B Arnswalde i II D Gross Born, „Łambinowicki Rocznik Muzealny” 2015, t. XXXVIII, s. 143-145.

Rozkaz obozowy nr 93. Podziat Stalagu VIII B, ,Szkice z dziejów obozów w Lamsdorf/Łambinowicach. Historia i współczesność", z. 3, red. E. Nowak, Opole 2007, s. 128.

Sadzewicz M., Oflag II D Gross Born, Warszawa 1977, s. 118-119.

\section{OPRACOWANIA}

Banik J., Kobylarz R., „...Podeptali godność narodu niemieckiego”. Rassenschande w rejencji opolskiej (1939-1945), „Studia Śląskie” 2007, t. LXVI, s. 39-57.

Bednorz R., Żotnierze brytyjscy za drutami Stalagów VIII B i 344 w Lamsdorf-Eambinowicach, „Łambinowicki Rocznik Muzealny” 1993, t. XVI, s. 9-27.

Datner S., Ucieczki z niewoli niemieckiej 1939-1945, Warszawa 1966, s. 54-55.

Flemming M., Jeńcy wojenni. Studium prawno-historyczne, Warszawa 2000.

Jeńcy sowieccy na ziemiach polskich $w$ czasie II wojny światowej, red. J. Wojtkowiak, Warszawa 2015.

Kobylarz R., Sznotala K., Niemiecki system jeniecki 1939-1945. Wykaz obozów, Opole 2010.

Matuchniak-Krasuska A., Za drutami oflagów. Jeniec wojenny 613/X A, Opole 2016.

Nowak E., Powstańcy słowaccy w Stalagu 344 Lamsdorf (1944-1945), „Szkice z dziejów obozów w Lamsdorf/Łambinowicach. Historia i współczesność”, z. 2, red. E. Nowak, Opole 2000, s. $75-84$.

Półchłopek W., Igrzyska olimpijskie w obozach jenieckich (1940 i 1944), „, Łambinowicki Rocznik Muzealny" 1996, t. XIX, s. 21-28.

Półchłopek W., Ucieczki z obozów jenieckich Lamsdorf (1944-1945), „Szkice z dziejów obozów w Lamsdorf/Łambinowicach. Historia i współczesność”, z. 2, red. E. Nowak, Opole 2000, s. $85-100$.

Sawczuk J., Senft S., Obozy jenieckie w Lamsdorf w latach II wojny światowej, [w:] Obozy w Lamsdorf/Eambinowicach (1870-1946), red. E. Nowak, Opole 2006, s. 117-260. 
Senft S., Włoscy jeńcy wojenni w Stalagu 344, „,Szkice z dziejów obozów w Lamsdorf / Łambinowicach. Historia i współczesność”, z. 2, red. E. Nowak, Opole 2000, s. 61-74.

Skowronek T., Wbrew regulaminowi. Wspótpraca Maksymiliana Kreutzingera z Ernestem Heimem w Oflagu II D Gross Born, [w:] Zwykty żolnierski los. Jeńcy wojenni na Pomorzu Zachodnim (1939-1945), red. J. Aniszewska, R. Kobylarz-Buła, P. Stanek, Opole 2011, s. 179-192.

Stanek P., Jeńcy w kajdanach: casus uczestników rajdu na Dieppe, „Przegląd Historyczny” 2014, t. CV, nr 4, s. 633-643.

Stanek P., Niewola powstańców warszawskich (1944-1945), „Dzieje Najnowsze” 2012, nr 2, s. $51-67$.

Stanek P., Przystanek Lamsdorf. Powstańcy warszawscy w obozie jenieckim Stalag 344, seria: „Jeńcy Lamsdorf”, t. I, Opole 2015.

Stanek P., W niewoli niemieckiej. Informator wystawy statej Centralnego Muzeum Jeńców Wojennych w Lambinowicach-Opolu, Opole 2011.

Stanek P., Wrześniowy epilog. Żotnierze Wojska Polskiego w obozach Lamsdorf, seria: „Jeńcy Lamsdorf', t. IV, Opole 2017.

Wickiewicz A., Niewola w brytyjskim mundurze. Stalag VIII B (344) Lamsdorf, seria: „Jeńcy Lamsdorf", t. II, Opole 2016.

Zeszyt zadań do wystawy stałej „W niewoli niemieckiej”, oprac. A. Wickiewicz, B. Bezpałko, D. Musiał, P. Stanek, Opole 2012.

\section{Netografia}

http://voenspez.ru/index.php?topic=23128.0;wap2 http://vmg.vsbinfo.de/e/fehlertabelle.htm.

http://www.anhaltspunkte.de/vmg/e/fehlertabelle.htm.

http://www.documentarchiv.de/ksr/1872/militaerstrafgesetzbuch_deutsches-reich.html.

http://www.lexikon-der-wehrmacht.de/Gliederungen/Kriegsgefangenenlager/Dulag.htm.

\section{EWELINA KLIMCZAK}

\section{The guard service in Stalag VIII B Lamsdorf during World War II Regulations and reality}

\footnotetext{
The guard service at Lamsdorf and other Wehrmacht POW camps was governed by regulations which set out in details the scope of duties and rules of conduct. However, the manner in which they fulfilled their duties often deviated from the guidelines contained in the regulations issued by their superiors. The monotony of service, the desire to gain scarce goods, or even striving to improve their material situation encouraged the soldiers to violate the rules to which they were subjected. The guards' problems with the law and regulations are quite an important issue, because they are related, among others, with their attitude towards and treatment of prisoners-of-war.
}

Keywords: captivity, prisoner of war, stalag, guard service. 